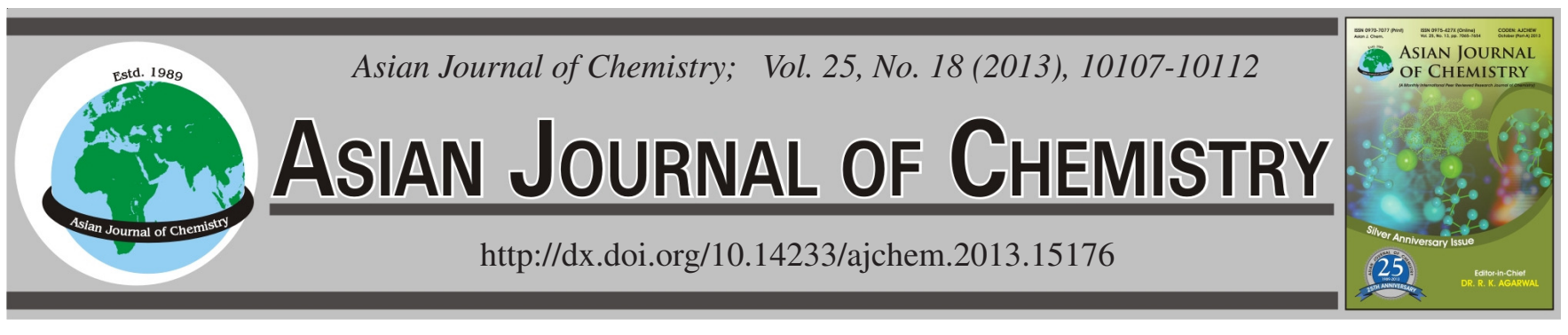

\title{
Single Crystal Structure and Characterization of 2-Amino-4-methylpyridinium-4-nitrophenolate-4-nitrophenol
}

\section{S. Muralidharan ${ }^{1}$, P. Nagapandiselvi ${ }^{1}$, T. Srinivasan ${ }^{2}$, Y. Vidyalakshmi $^{1}$, D. Velmurugan ${ }^{2}$ and R. Gopalakrishnan ${ }^{1, *}$}

${ }^{1}$ Department of Physics, Anna University, Chennai-600 025, India

${ }^{2}$ Centre of Advanced Study in Crystallography and Biophysics, University of Madras, Guindy Campus, Chennai-600 025, India

*Corresponding author: Fax: +91 44 22358700; Tel: +91 44 22358710/8707; E-mail: krgkrishnan@ annauniv.edu; krgkrishnan@yahoo.com

(Received: 17 January 2013;

Accepted: 8 November 2013)

AJC-14345

\begin{abstract}
This report presents the synthesis, growth, crystal structure determination and characterization of 2-amino-4-methylpyridinium-4nitrophenolate-4-nitrophenol (2A4MPPP). The crystal structure of the title compound, $\mathrm{C}_{18} \mathrm{H}_{18} \mathrm{~N}_{4} \mathrm{O}$, was determined by X-ray diffraction at $293 \mathrm{~K}$. It was in orthorhombic crystal system with a space group Pna2 $(Z=4)$ and lattice parameters: $a=13.0726(6) \AA, b=11.8157(4)$ $\AA$ and $\mathrm{c}=12.0281(5) \AA, \mathrm{V}=1857.88(13) \AA^{3}$. FT-IR, FT-Raman, UV-DRS spectra were employed to characterize the crystal. Thermal stability of the crystal was explored by TG-DSC analysis. The thermal analysis revealed that the melting point of the as grown crystal is $98.8^{\circ} \mathrm{C}$. Vicker's microhardness test was performed to analyze the mechanical strength of the as grown crystal. The second harmonic generation efficiency of the 2-amino-4-methylpyridinium-4-nitrophenolate-4-nitrophenol measured using Kurtz and Perry powder technique was high and is about 1.9 times that of well known standard potassium dihydrogen phosphate for particle size less than $180 \mu$. The results reveal that 2-amino-4-methylpyridinium-4-nitrophenolate-4-nitrophenol is a phase matchable non-linear optical material.
\end{abstract}

Key Words: Crystal structure, Non-linear optical material, 2-Amino-4-methylpyridine, 4-Nitrophenol.

\section{INTRODUCTION}

In the recent years, a great deal of effort has been expanded on the identification and development of organic materials and they have been widely studied as candidate for all-optical devices because they have many exciting properties that are almost continuously "tunable", telecommunications, frequency mixing, electro-optic modulation, optical parametric oscillation and other applications ${ }^{1,2}$. The second and third order nonlinear optical properties of various organic materials have been extensively investigated through many experimental and theoretical methods ${ }^{3,4}$. The large second order optical nonlinearity originates from organic $\pi$ conjugated molecules having an electron acceptor group at one end and donor group at the opposite end ${ }^{5-7}$. It is well established that donor acceptor compounds with their large differences between ground state and excited state and dipole moments as well as large transition dipole moments can exhibit large molecular second order optical nonlinearities $^{8-10}$. The growth of high quality single crystals is a fundamental step in the investigation of the properties of a new material and progress towards technological applications. Finding ways to ensure that a bulk material is acentric has been a serious hurdle in the design of new organic materials for non-linear optical uses. Srinivasan et $a l .{ }^{11}$ reported dimethyl amino pyridinium-4-nitrophenolate-4-nitrophenol with high second harmonic generation efficiency and similarly Anandha babu et al. ${ }^{12}$ reported 2-aminopyridinium-4-nitrophenolate-4nitrophenol with high second harmonic generation efficiency. In continuation of such reports, in this article, we report growth, structure and properties of a new NLO pyridine based crystal, 2-amino-4-methylpyridinium-4-nitrophenolate-4-nitrophenol (2A4MPPP). Presence of amino and methyl groups in pyridine at 2 nd and 4th positions respectively, can significantly enhance the basic strength of pyridine nitrogen. Hence the crystal is expected to have high electron delocalization compared to dimethyl amino pyridinium-4-nitrophenolate-4-nitrophenol and 2-aminopyridinium-4-nitrophenolate-4-nitrophenol. It is an ionic crystal in which a proton transfer occurred from 4-nitrophenol to 2-amino-4-methylpyridine. A neutral 4-nitrophenol rests as a third partner. Experiments showed that 2A4MPPP crystal possesses higher second harmonic generation efficiency compared with the well known potassium dihydrogen phosphate (KDP).

\section{EXPERIMENTAL}

2-Amino-4-methylpyridine and 4-nitrophenol were mixed in the molar ratio of 1:2 in ethanol and the prepared solution was stirred well for $5 \mathrm{~h}$ to obtain homogeneity. After dissolving, 
the mixed solution was filtered to eliminate indissoluble impurity. Then the solution was closed with a perforated polythene cover and placed in a dust free atmosphere for slow evaporation at room temperature. The synthesized salt was purified by successive recrystallisation and utilized for growth of 2A4MPPP crystal. The as-grown crystal which was obtained after a period of 15 days is shown in Fig. 1. Crystallographic data have been deposited with Cambridge Crystallographic Data Centre: Deposition number CCDC 865373. Copies of the data can be obtained free of charge via http://www. ccdc.cam.ac.uk/conts/retrieving.html (or from the Cambridge Crystallographic Data Centre, 12, Union Road, Cambridge, CB2 1EZ, UK; Fax: +44 1223 336033; e-mail: deposit@ccdc.cam.ac.uk).

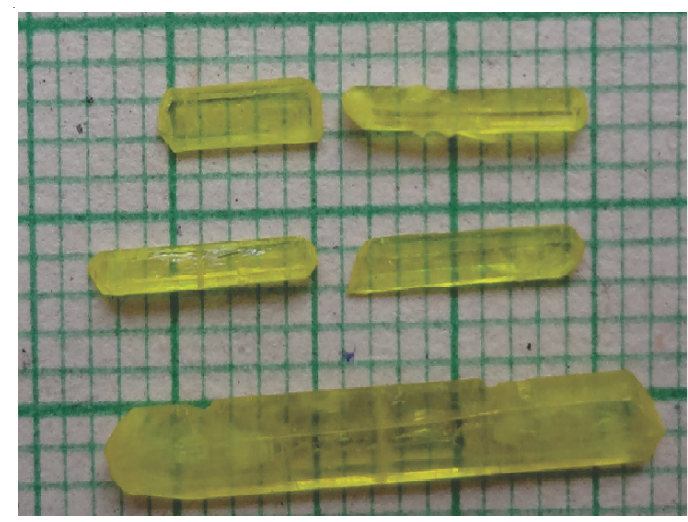

Fig. 1. As grown single crystals of 2A4MPPP

General procedure: X-Ray diffraction studies for the crystal was carried out using a Bruker AXS Kappa APEX II single crystal CCD diffractometer equipped with graphitemonochromated $\operatorname{MoK}_{\alpha}(\lambda=0.7107 \AA)$ radiation. The diffractometer is equipped with four circle Kappa goniometer. A crystal of size $(0.30 \mathrm{~mm} \times 0.25 \mathrm{~mm} \times 0.25 \mathrm{~mm})$ was cut and mounted on a glass fiber using cyanoacrylate. The unit cell parameters were determined by collecting the diffracted intensities in 36 frames measured in three different crystallographic zones and using the method of difference vectors. Intensity data were collected at $293 \mathrm{~K}$ using $\omega-\varphi$ scan modes. The data were corrected for the Lorentz and polarization effects. The absorption empirical correction was effected using multi-scan procedure. The crystal structure was solved by direct methods with the SIR92 program and refined by full matrix least-squares with SHELXL-97 program to an $\mathrm{R}$ value of 0.0526 . The thermal ellipsoid representation of the molecule was performed with ORTEP3 program. The crystal structure and packing diagram of 2A4MPPP crystal are shown in Figs. 2 and 3.

The FT-IR spectrum in the range of $4000-400 \mathrm{~cm}^{-1}$ was recorded on Perkin Elmer FT-IR spectrometer using $\mathrm{KBr}$ pellet technique. The FT Raman spectrum of the crystal was recorded using BRUKER RFS 27. The electronic absorption spectrum was recorded using Schimadzu 1601 UV-visible spectrophotometer. Thermogravimetric and differential scanning calorimetry analyses were recorded in the nitrogen atmosphere between 28 and $500{ }^{\circ} \mathrm{C}$ at a heating rate of $10^{\circ} \mathrm{C} / \mathrm{min}$, using an instrument NETZSCH STA 449 F3 JUPI-TER. Mechanical strength of 2A4MPPP crystal was assessed by Matsuzawa MMT-X7B

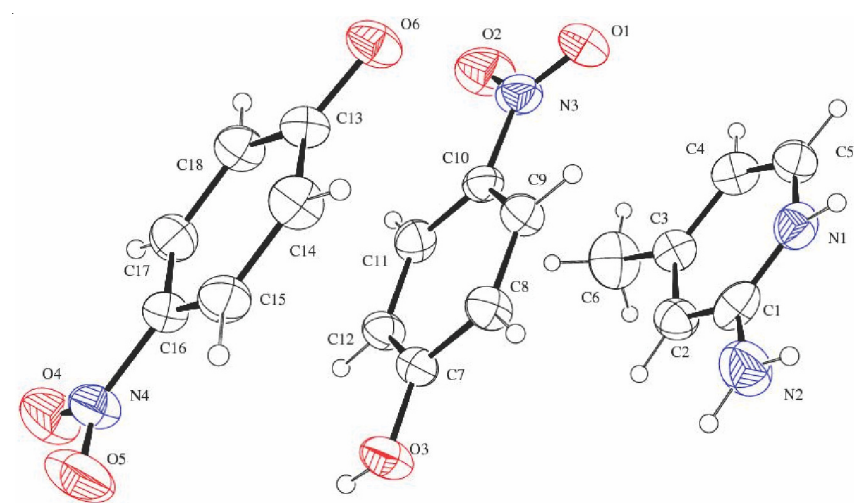

Fig. 2. Molecular structure of the 2A4MPPP, showing displacement ellipsoids drawn at the $30 \%$ probability level. $\mathrm{H}$ atoms are presented as small spheres of arbitrary radius

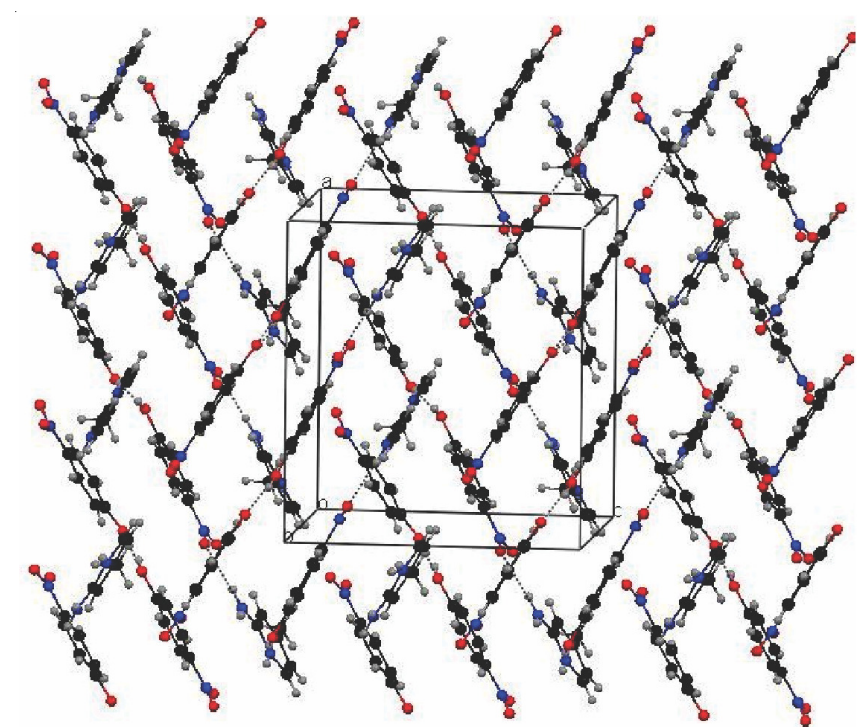

Fig. 3. Crystal packing diagram of title compound viewed along 'b' axis, showing the hydrogen bonds

microhardness tester fitted with a diamond pyramidal indenter. Selected smooth surface of the crystal was subjected to the indentation; diagonal length of the intended impression was measured by varying load from 1-50 g. The indentation time was kept as $5 \mathrm{~s}$ for all the loads. For each load several trials were made and the average value of the diagonal length of the indentation marks was obtained.

The second harmonic generation efficiency of the title compound was compared with standard potassium dihydrogen phosphate (KDP) using Kurtz-Perry ${ }^{13}$ technique. The powdered sample of the crystal was densely packed between two transparent glass slides. Radiation from Q-switched Nd-YAG laser operating at $1064 \mathrm{~nm}$ and $8 \mathrm{~ns}$ pulse width with an input repetition rate of $10 \mathrm{~Hz}$ and energy $0.68 \mathrm{~mJ} /$ pulse, was radiated directly on the powder. The output energy was measured using power and energy meter (EPM 2000, sensor Head II, model: $\mathrm{J}-50-\mathrm{MB}-\mathrm{YAG}$, energy range: $1.5 \mathrm{~mJ}$ to $3 \mathrm{~J}$ ). To confirm the existence of phase matching property, the dependence of second harmonic generation intensity on particle size, both 2A4MPPP and potassium dihydrogen phosphate was powdered and sieved using sieve shaker (Model: Haver EML digital test sieve shaker) into distinct particle size ranges (i.e.) below 90 , 90-180, 180-250 and 250-355 $\mu \mathrm{m}$. 


\section{RESULTS AND DISCUSSION}

In the crystal 4-nitrophenol ionizes to form 4-nitrophenolate ion and free proton. The free proton is picked up by 2-amino-4-methylpyridine to form 2-amino-4-methylpyridinium ion. In the unit cell unionised 4-nitrophenol is also present. The reaction is given below:

$$
\begin{array}{r}
\mathrm{C}_{6} \mathrm{H}_{8} \mathrm{~N}_{2}+2\left(\mathrm{C}_{6} \mathrm{H}_{4} \mathrm{NO}_{2} \mathrm{OH}\right) \longrightarrow \\
\mathrm{C}_{6} \mathrm{H}_{9} \mathrm{~N}_{2}{ }^{+} \cdot \mathrm{C}_{6} \mathrm{H}_{4} \mathrm{NO}_{2} \mathrm{O}^{-} . \mathrm{C}_{6} \mathrm{H}_{4} \mathrm{NO}_{2} \mathrm{OH}
\end{array}
$$

The compound 2A4MPPP belongs to the orthorhombic system with a space group Pna $2_{1}$ having four molecules in the unit cell. The lattice parameters are $\mathrm{a}=13.0726(6) \AA, \mathrm{b}=$ $11.8157(4) \AA, c=12.0281(5) \AA$ and with a cell volume of 1857.88(13) $\AA^{3}$. The crystallographic data are represented in Table-1. The molecular structure of 2-amino-4-methylpyridinium-4-nitrophenolate-4-nitrophenol is shown in Fig. 2, which clearly shows that the crystal structure consists of 2-amino-4-methylpyridinium cations, 4-nitrophenolate anions and 4-nitrophenol molecules. The 2A4MPPP crystal has two 4-nitrophenol groups, one acts as a proton donor and is electronegative while the other one is neutral. In the title compound, $\mathrm{N}$ hetero atom in the pyridine ring is engaged in strong $\mathrm{N}-\mathrm{H}$-..O hydrogen bonding with the phenolate anion. The packing diagram is shown in Fig. 3. The dihedral angle between pyridine ring $(\mathrm{N} 1 / \mathrm{C} 1 / \mathrm{C} 2 / \mathrm{C} 3 / \mathrm{C} 4 / \mathrm{C} 5)$ and the phenyl ring $(\mathrm{C} 7 /$ $\mathrm{C} 8 / \mathrm{C} 9 / \mathrm{C} 10 / \mathrm{C} 11 / \mathrm{C} 12)$ are $4.93(18)^{\circ}$, the dihedral angle between pyridine ring and the other phenyl ring (C13/C14/ $\mathrm{C} 15 / \mathrm{C} 16 / \mathrm{C} 17 / \mathrm{C} 18)$ is $5.32(18)^{\circ}$. The dihedral angle between the two phenyl rings is $3.74(17)^{\circ}$. The nitrogen atom N2 attached with the phenyl ring deviate by $0.0109(5) \AA$, while the methyl group carbon atom C6 attached with the pyridine ring deviate by $0.0535(6) \AA$. The nitro group (N3/O1/O2) attached with the phenyl ring makes a dihedral angle of $3.36(3)^{\circ}$, the hydroxyl oxygen atom $\mathrm{O} 3$ attached with the phenyl ring deviate by 0.0200 (3) $\AA$. The nitro group (N4/O4/ O5) attached with the other phenyl ring makes a dihedral angle of $3.47(3)^{\circ}$. The hydroxyl oxygen atom $\mathrm{O} 6$ attached with the phenyl ring deviate by $-0.0822(3) \AA$. The pyridine ring adopts a planar confirmation with a maximum deviation of $0.0008(4)$ $\AA$. The phenyl rings also adopt a planar conformation with a maximum deviation of 0.0008(4) and 0.010(4) A, respectively. The crystal structure is stabilized by strong N-H..O and C$\mathrm{H}$... O hydrogen bonds which results in the formation of a three dimensional network. The Hydrogen-bond geometry $(\AA)$, the selected bond lengths and the selected bond angles are listed in Tables 2-4, respectively.

The FTIR spectrum of the crystal is shown in Fig. 4. The symmetric and asymmetric stretching vibrations of the $\mathrm{NH}_{2}$ group showed peaks at 3337 and $3427 \mathrm{~cm}^{-1}$. The $\mathrm{OH}$ stretching vibration of 4-nitrophenol was not distinctly seen hence it must be ionized and transferred to pyridine nitrogen as shown in the ORTEP diagram. In the ORTEP diagram one of the phenol molecules carries phenolic $\mathrm{OH}$ group, even then the $\mathrm{OH}$ stretching region was not broad. The stretching vibrations of the $\mathrm{CH}_{3}$ group were observed at 2892 and $2806 \mathrm{~cm}^{-1}$. The $\mathrm{C}-\mathrm{H}$ stretching vibration of the aromatic rings occurred at 3098 $\mathrm{cm}^{-1}$. The pyridine ring vibrations yielded peaks at 1668 and $1625 \mathrm{~cm}^{-1}$. The peaks at 1579 and $1483 \mathrm{~cm}^{-1}$ were assigned to
TABLE-1

CRYSTAL DATA AND STRUCTURE REFINEMENT FOR 2A4MPPP

\begin{tabular}{ll}
\hline Empirical formula & $\mathrm{C}_{18} \mathrm{H}_{18} \mathrm{~N}_{4} \mathrm{O}_{6}$ \\
Formula weight & 386.36 \\
Temperature & $293(2) \mathrm{K}$ \\
Wavelength & $0.71073 \AA$ \\
Crystal system, space group & Orthorhombic, Pna $2_{1}$ \\
Unit cell dimensions & $\mathrm{a}=13.0726(6) \AA \AA^{\circ} \alpha=90^{\circ}$ \\
& $\mathrm{b}=11.8157(4) \AA \AA \AA=90^{\circ}$ \\
& $\mathrm{c}=12.0281(5) \AA \gamma=90^{\circ}$ \\
Volume & $1857.88(13) \AA^{3}$ \\
Z, Calculated density & $4,1.381 \mathrm{Mg} / \mathrm{m}^{3}$ \\
Absorption coefficient & $0.106 \mathrm{~mm}^{-1}$ \\
F(000) & 808 \\
Crystal size & $0.30 \mathrm{~mm}^{3} \times 0.25 \mathrm{~mm} \times 0.25 \mathrm{~mm}$ \\
Theta range for data collection & 2.32 to $24.94^{\circ}$ \\
Limiting indices & $-15 \leq \mathrm{h} \leq 15,-14 \leq \mathrm{k} \leq 12$, \\
& $-14 \leq 1 \leq 14$ \\
Reflections collected/unique & $18963 / 3224\left[\mathrm{R}_{\text {(int) }}=0.0462\right]$ \\
Completeness to theta & $24.94,99.9 \%$ \\
Absorption correction & $\mathrm{Semi}-\mathrm{empirical} \mathrm{from} \mathrm{equivalents}$ \\
Max. and min. transmission & 0.9740 and 0.9089 \\
Refinement method & Full-matrix least-squares on $\mathrm{F}^{2}$ \\
Data / restraints / parameters & $3224 / 2 / 258$ \\
Goodness-of-fit on $\mathrm{F}^{2}$ & 1.036 \\
Final R indices [I $2 \sigma(\mathrm{I})]$ & $\mathrm{R}_{1}=0.0526, \mathrm{wR}_{2}=0.1618$ \\
R indices (all data) & $\mathrm{R}_{1}=0.0632, \mathrm{wR}_{2}=0.1744$ \\
Absolute structure parameter & $1.4(18)$ \\
Extinction coefficient & $0.0040(16)$ \\
Largest diff. peak and hole & 0.665 and $-0.283 \mathrm{eA} \mathrm{A}^{-3}$ \\
\hline &
\end{tabular}

TABLE-2

HYDROGEN-BOND GEOMETRY (̊)

\begin{tabular}{lcccc}
\hline \multicolumn{1}{c}{$\mathrm{D}-\mathrm{H} \cdots \mathrm{A}$} & $\mathrm{D} \cdots \mathrm{H}$ & $\mathrm{H} \cdots \mathrm{A}$ & $\mathrm{D} \cdots \mathrm{A}$ & $\mathrm{D}-\mathrm{H} \cdots \mathrm{A}$ \\
\hline $\mathrm{N}(1)-\mathrm{H}(1 \mathrm{~A}) \cdots \mathrm{O}(6)^{\mathrm{i}}$ & $0.935(19)$ & $1.714(17)$ & $2.597(3)$ & $156(4)$ \\
$\mathrm{N}(2)-\mathrm{H}(2 \mathrm{~A}) \cdots \mathrm{O}(6)^{\mathrm{i}}$ & 0.86 & 2.41 & $3.099(4)$ & 137 \\
$\mathrm{~N}(2)-\mathrm{H}(2 \mathrm{~B}) \cdots \mathrm{O}(2)^{\mathrm{ii}}$ & 0.86 & 2.18 & $3.007(5)$ & 162 \\
$\mathrm{O}(3)-\mathrm{H}(3) \cdots \mathrm{O}(6)^{\mathrm{iii}}$ & 0.82 & 1.78 & $2.582(3)$ & 165 \\
$\mathrm{C}(2)-\mathrm{H}(2) \cdots \mathrm{O}(1)^{\mathrm{ii}}$ & 0.93 & 2.56 & $3.394(5)$ & 149 \\
$\mathrm{C}(4)-\mathrm{H}(4) \cdots \mathrm{O}(5)^{\mathrm{iii}}$ & 0.93 & 2.48 & $3.239(5)$ & 139 \\
\hline
\end{tabular}

Symmetry codes: (i) -x,-y, 1/2+z (ii) $1 / 2+x, 1 / 2-y, z$ (iii)-1/2+x, 1/2-y, $1+\mathrm{z}$.

\begin{tabular}{cccc}
\multicolumn{4}{c}{ TABLE-3 } \\
& SELECTED BOND LENGTHS $(\AA)$ \\
\hline $\begin{array}{c}\text { Selected } \\
\text { bonds }\end{array}$ & $\begin{array}{c}\text { Bond lengths } \\
(\AA)\end{array}$ & $\begin{array}{c}\text { Selected } \\
\text { bonds }\end{array}$ & $\begin{array}{c}\text { Bond lengths } \\
(\AA)\end{array}$ \\
\hline $\mathrm{C}(1)-\mathrm{N}(2)$ & $1.304(5)$ & $\mathrm{C}(10)-\mathrm{N}(3)$ & $1.432(4)$ \\
$\mathrm{C}(1)-\mathrm{N}(1)$ & $1.330(5)$ & $\mathrm{C}(11)-\mathrm{C}(12)$ & $1.384(5)$ \\
$\mathrm{C}(1)-\mathrm{C}(2)$ & $1.395(5)$ & $\mathrm{C}(13)-\mathrm{O}(6)$ & $1.299(4)$ \\
$\mathrm{C}(2)-\mathrm{C}(3)$ & $1.382(5)$ & $\mathrm{C}(13)-\mathrm{C}(14)$ & $1.396(5)$ \\
$\mathrm{C}(3)-\mathrm{C}(4)$ & $1.406(6)$ & $\mathrm{C}(13)-\mathrm{C}(18)$ & $1.405(5)$ \\
$\mathrm{C}(3)-\mathrm{C}(6)$ & $1.487(5)$ & $\mathrm{C}(14)-\mathrm{C}(15)$ & $1.398(5)$ \\
$\mathrm{C}(4)-\mathrm{C}(5)$ & $1.352(6)$ & $\mathrm{C}(15)-\mathrm{C}(16)$ & $1.349(5)$ \\
$\mathrm{C}(5)-\mathrm{N}(1)$ & $1.331(6)$ & $\mathrm{C}(16)-\mathrm{C}(17)$ & $1.378(5)$ \\
$\mathrm{C}(7)-\mathrm{O}(3)$ & $1.326(4)$ & $\mathrm{C}(16)-\mathrm{N}(4)$ & $1.428(4)$ \\
$\mathrm{C}(7)-\mathrm{C}(12)$ & $1.383(5)$ & $\mathrm{C}(17)-\mathrm{C}(18)$ & $1.389(5)$ \\
$\mathrm{C}(7)-\mathrm{C}(8)$ & $1.389(5)$ & $\mathrm{N}(3)-\mathrm{O}(1)$ & $1.215(4)$ \\
$\mathrm{C}(8)-\mathrm{C}(9)$ & $1.372(5)$ & $\mathrm{N}(3)-\mathrm{O}(2)$ & $1.243(4)$ \\
$\mathrm{C}(9)-\mathrm{C}(10)$ & $1.383(5)$ & $\mathrm{N}(4)-\mathrm{O}(5)$ & $1.215(5)$ \\
$\mathrm{C}(10)-\mathrm{C}(11)$ & $1.391(5)$ & $\mathrm{N}(4)-\mathrm{O}(4)$ & $1.225(5)$ \\
\hline
\end{tabular}

ring vibrations of 4-nitrophenol. The asymmetric stretching vibration of the nitro group overlapped with the peak at 1483 $\mathrm{cm}^{-1}$. The symmetric vibration of $\mathrm{NO}_{2}$ group occurred at 1320 
TABLE-4

SELECTED BOND ANGLES $\left({ }^{\circ}\right)$ FOR 2A4MPPP

\begin{tabular}{cccc}
$\begin{array}{c}\text { Selected bond } \\
\text { angles }\end{array}$ & $\begin{array}{c}\text { Angles } \\
\left({ }^{\circ}\right)\end{array}$ & $\begin{array}{c}\text { Selected bond } \\
\text { angles }\end{array}$ & $\begin{array}{c}\text { Angles } \\
\left({ }^{\circ}\right)\end{array}$ \\
\hline $\mathrm{N}(2)-\mathrm{C}(1)-\mathrm{N}(1)$ & $114.1(4)$ & $\mathrm{C}(7)-\mathrm{C}(12)-\mathrm{C}(11)$ & $119.9(3)$ \\
$\mathrm{N}(2)-\mathrm{C}(1)-\mathrm{C}(2)$ & $125.4(4)$ & $\mathrm{O}(6)-\mathrm{C}(13)-\mathrm{C}(14)$ & $121.5(3)$ \\
$\mathrm{N}(1)-\mathrm{C}(1)-\mathrm{C}(2)$ & $120.4(3)$ & $\mathrm{O}(6)-\mathrm{C}(13)-\mathrm{C}(18)$ & $121.2(3)$ \\
$\mathrm{C}(3)-\mathrm{C}(2)-\mathrm{C}(1)$ & $119.0(4)$ & $\mathrm{C}(14)-\mathrm{C}(13)-\mathrm{C}(18)$ & $117.3(3)$ \\
$\mathrm{C}(2)-\mathrm{C}(3)-\mathrm{C}(4)$ & $118.2(3)$ & $\mathrm{C}(13)-\mathrm{C}(14)-\mathrm{C}(15)$ & $121.2(3)$ \\
$\mathrm{C}(2)-\mathrm{C}(3)-\mathrm{C}(6)$ & $121.3(4)$ & $\mathrm{C}(16)-\mathrm{C}(15)-\mathrm{C}(14)$ & $119.4(3)$ \\
$\mathrm{C}(4)-\mathrm{C}(3)-\mathrm{C}(6)$ & $120.5(4)$ & $\mathrm{C}(15)-\mathrm{C}(16)-\mathrm{C}(17)$ & $121.7(3)$ \\
$\mathrm{C}(5)-\mathrm{C}(4)-\mathrm{C}(3)$ & $119.7(4)$ & $\mathrm{C}(15)-\mathrm{C}(16)-\mathrm{N}(4)$ & $119.4(3)$ \\
$\mathrm{N}(1)-\mathrm{C}(5)-\mathrm{C}(4)$ & $121.3(4)$ & $\mathrm{C}(17)-\mathrm{C}(16)-\mathrm{N}(4)$ & $118.8(3)$ \\
$\mathrm{O}(3)-\mathrm{C}(7)-\mathrm{C}(12)$ & $122.9(3)$ & $\mathrm{C}(16)-\mathrm{C}(17)-\mathrm{C}(18)$ & $119.3(3)$ \\
$\mathrm{O}(3)-\mathrm{C}(7)-\mathrm{C}(8)$ & $117.2(3)$ & $\mathrm{C}(17)-\mathrm{C}(18)-\mathrm{C}(13)$ & $121.0(3)$ \\
$\mathrm{C}(12)-\mathrm{C}(7)-\mathrm{C}(8)$ & $120.0(3)$ & $\mathrm{C}(1)-\mathrm{N}(1)-\mathrm{C}(5)$ & $121.3(3)$ \\
$\mathrm{C}(9)-\mathrm{C}(8)-\mathrm{C}(7)$ & $120.7(3)$ & $\mathrm{O}(1)-\mathrm{N}(3)-\mathrm{O}(2)$ & $121.9(3)$ \\
$\mathrm{C}(8)-\mathrm{C}(9)-\mathrm{C}(10)$ & $119.2(3)$ & $\mathrm{O}(1)-\mathrm{N}(3)-\mathrm{C}(10)$ & $119.9(3)$ \\
$\mathrm{C}(9)-\mathrm{C}(10)-\mathrm{C}(11)$ & $121.0(3)$ & $\mathrm{O}(2)-\mathrm{N}(3)-\mathrm{C}(10)$ & $118.2(3)$ \\
$\mathrm{C}(9)-\mathrm{C}(10)-\mathrm{N}(3)$ & $118.2(3)$ & $\mathrm{O}(5)-\mathrm{N}(4)-\mathrm{O}(4)$ & $121.8(4)$ \\
$\mathrm{C}(11)-\mathrm{C}(10)-\mathrm{N}(3)$ & $120.8(3)$ & $\mathrm{O}(5)-\mathrm{N}(4)-\mathrm{C}(16)$ & $118.6(4)$ \\
$\mathrm{C}(12)-\mathrm{C}(11)-\mathrm{C}(10)$ & $119.3(3)$ & $\mathrm{O}(4)-\mathrm{N}(4)-\mathrm{C}(16)$ & $119.5(3)$
\end{tabular}

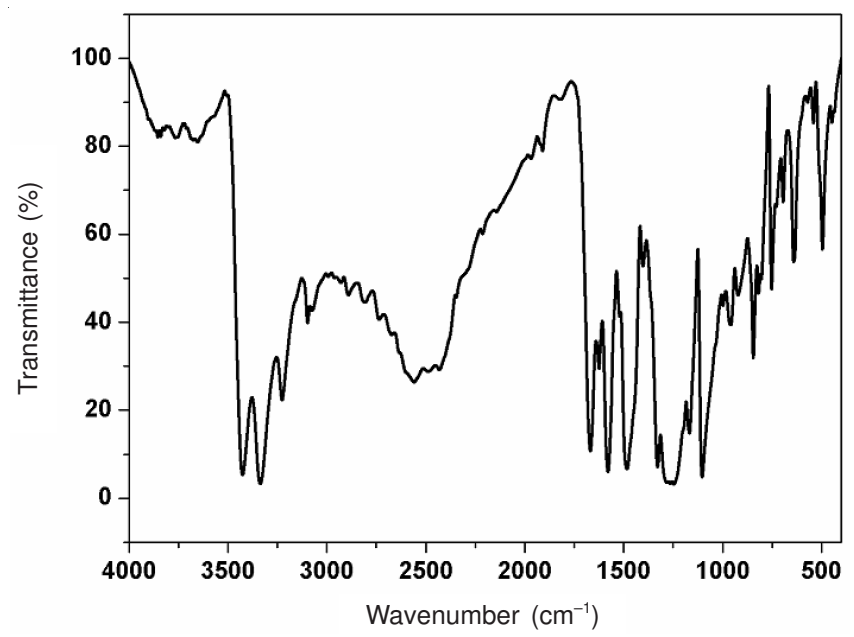

Fig. 4. FT-IR spectrum of 2A4MPPP

$\mathrm{cm}^{-1}$. The phenolic C-O stretching vibration yielded a broad intense peak at $1246 \mathrm{~cm}^{-1}$ due to hydrogen bonding with adjacent phenolic $\mathrm{OH}$ group. The sharp peak at $1160 \mathrm{~cm}^{-1}$ was also due to phenolic C-O stretching. The aromatic ring $\mathrm{C}-\mathrm{H}$ bending vibration of 4-nitrophenol occurred at $844 \mathrm{~cm}^{-1}$. Other groups of vibrations occurring below $1000 \mathrm{~cm}^{-1}$ were due to aromatic ring $\mathrm{C}-\mathrm{H}$ bending vibrations ${ }^{14}$.

The FT-Raman spectrum is shown in Fig. 5. The aromatic $\mathrm{CH}$ stretching vibration was very weak at $3076 \mathrm{~cm}^{-1}$. Similarly the aromatic ring vibrations occurring at 1590 and $1502 \mathrm{~cm}^{-1}$ were also weak. The $\mathrm{CH}_{3}$ bending modes at 1300 and 1329 $\mathrm{cm}^{-1}$ were intense. The peak at $1106 \mathrm{~cm}^{-1}$ was due to phenolic C-O stretching vibration. The $\mathrm{NH}_{2}$ and $\mathrm{NO}_{2}$ vibrations were weak as their bonds are very polar.

The UV-DRS spectra of 4-nitrophenol (4NP), 2-amino 4methyl pyridine (2A4MP) and 2-amino-4-methylpyridinium4-nitrophenolate-4-nitrophenol (2A4MPPP) are shown in Fig. 6 . The spectrum of 4-nitrophenol shows absorption maxima close to 470 and $315 \mathrm{~nm}$. They were assigned to $n-\pi^{*}$ and $\pi-\pi^{*}$ transitions respectively. The spectrum of 2-amino-4methylpyridine showed absorbance at $290 \mathrm{~nm}$. It was assigned

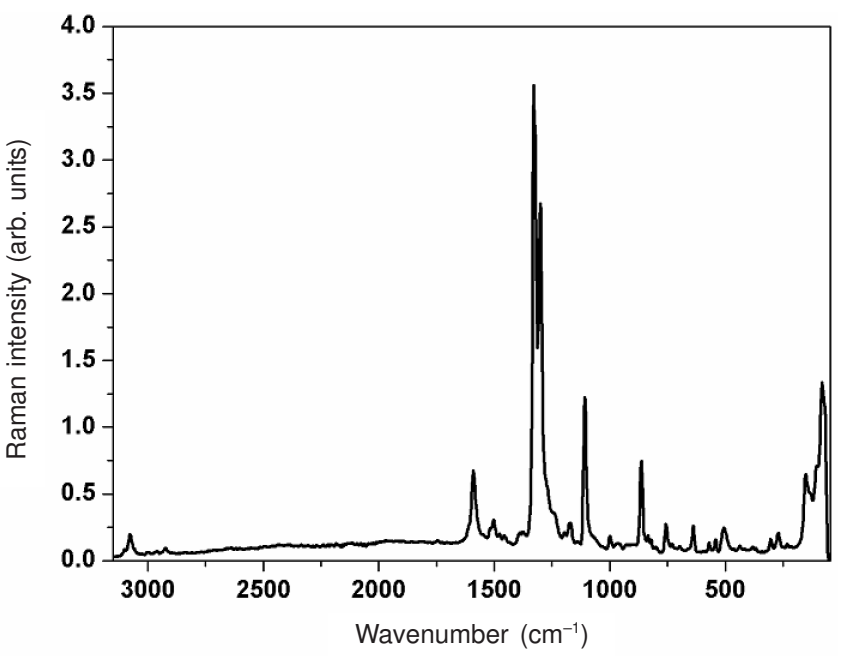

Fig. 5. FT Raman spectrum of 2A4MPPP

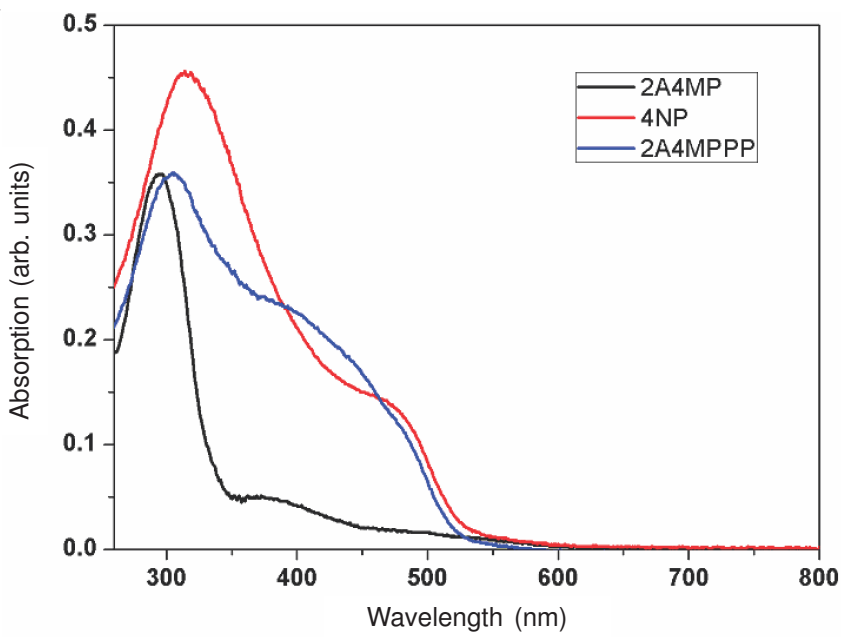

Fig. 6. UV-DRS absorption spectra of 2A4MP, 4NP and 2A4MPPP

to $\pi-\pi^{*}$ transition. The spectrum of 2-amino-4methyl-pyridine4-nitrophenolate-4-nitrophenol showed three absorbance maxima at 470, 400 and $305 \mathrm{~nm}$. The first absorption maximum overlapped with that of 4-nitrophenol and third absorption maximum matched with that of 2-amino-4-methylpyridine. The second absorption maximum was very much shifted to longer wavelength, which shows the conversion of 4-nitrophenol to 4-nitrophenolate and it was also supported by the single crystal XRD analysis. As well, there is no significant absorption at $532 \mathrm{~nm}$ indicating that this is a suitable material for second harmonic generation at $1064 \mathrm{~nm}$.

The results of TGA and DSC are illustrated in Fig. 7. The thermogram went straight up to $175^{\circ} \mathrm{C}$ illustrating absence of solvent in the crystal lattice. Above $175^{\circ} \mathrm{C}$, a major decomposition occurred leaving a residue of $25.4 \%$ at $500{ }^{\circ} \mathrm{C}$. It was due to decomposition of the components of the crystal. The results of the DSC analysis are illustrated in the same figure. The sharp endotherm starting at $98.8^{\circ} \mathrm{C}$ was due to melting. It was also verified by the determination of melting point by capillary method, in which the material started to melt at 98 ${ }^{\circ} \mathrm{C}$ (Instrumentation error $\pm 1{ }^{\circ} \mathrm{C}$ ). The TGA results showed decomposition at $175^{\circ} \mathrm{C}$ but an endotherm corresponding to it appeared very broad. The decomposition above $300{ }^{\circ} \mathrm{C}$ was 


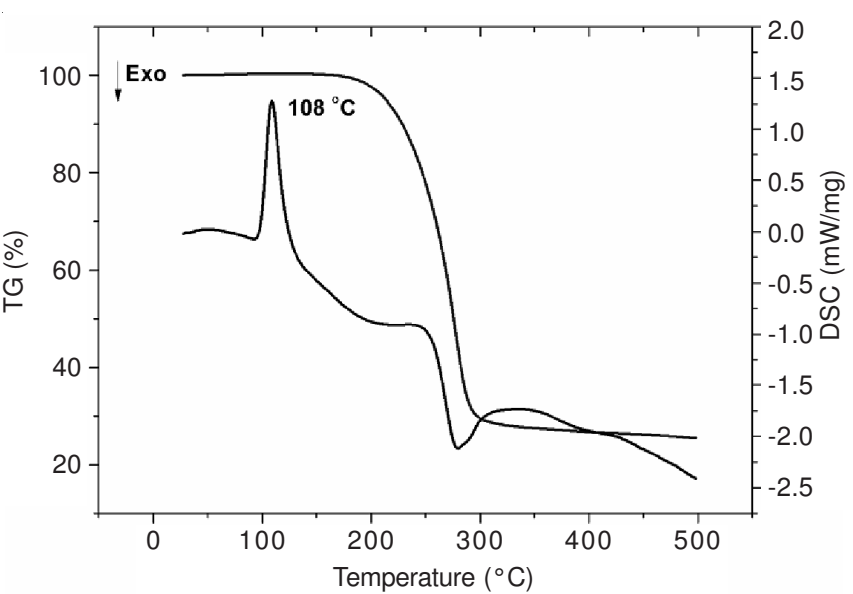

Fig. 7. TG and DSC curves of 2A4MPPP

also endothermic. Hence both the studies confirmed application of the crystal for NLO applications up to $98^{\circ} \mathrm{C}$.

Vickers hardness number was calculated by using the relation $\mathrm{H}_{\mathrm{v}}=1.8544\left(\mathrm{P} / \mathrm{d}^{2}\right)$. The resulting graph is shown in Fig. 8a. The apparent microhardness increases with increasing applied test load which shows the reverse indentation size effect and it may be attributed to the electrostatic attraction between para nitrophenolate ionic species present in the crystal and the bond between them.

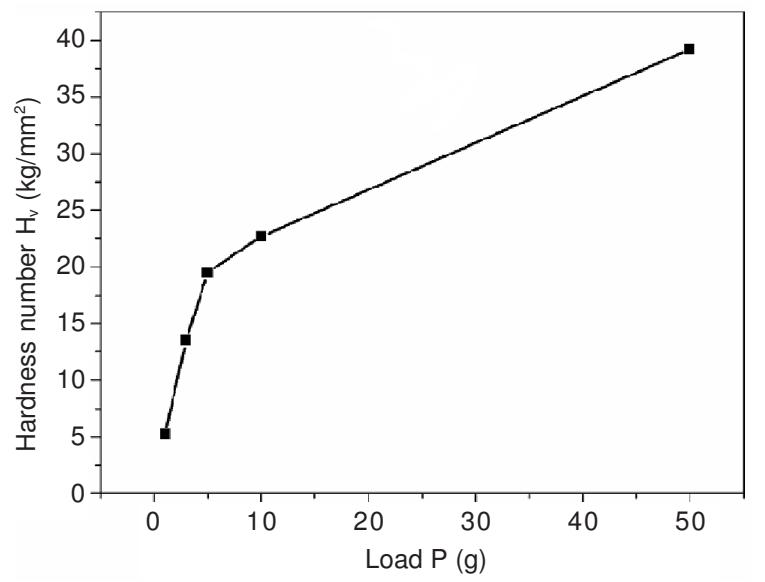

(a)

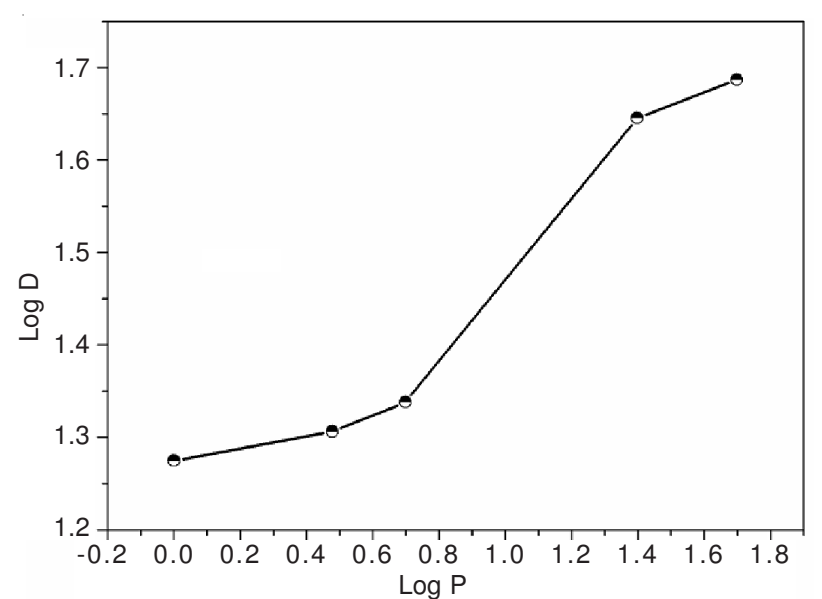

(b)

Fig. 8. (a) Variation of hardness with respect to load. (b) $\log \mathrm{p}$ versus $\log \mathrm{D}$
The relation between load and diagonal length was determined using $\mathrm{P}=\mathrm{kd}^{\mathrm{n}}$. According to Onitsch ${ }^{15}$ reported in Kick's correlation, that if the value of work hardening coefficient $\mathrm{n}<$ 2 , the hardness number decreases with increasing of load (ISE) that may be attributed to the hard material category. If $n>2$, hardness increases with increasing load (RISE) and the material comes under soft material category. The value of $n$ was calculated from the graph between $\log \mathrm{p}$ versus $\log \mathrm{d}$ and shown in the Fig. 8 b. It was found to be 2.4 and the grown crystal comes under the soft material category.

From the hardness value, the yield strength can be calculated using the following relation (1) for $n>2$

$$
\sigma_{y}=\frac{H_{V}}{2.9}[1-(n-2)]\left(\frac{12.5(n-2)}{1-(n-2)}\right)^{n-2}
$$

If $\mathrm{n}<2$ then the above equation reduces to

$$
\sigma_{\mathrm{y}}=\frac{\mathrm{H}_{\mathrm{V}}}{3}
$$

The value of yield strength was estimated using above equation and the graph shows the load dependent nature of yield strength ${ }^{16}$ as shown in Fig. 9a. The elastic stiffness constant $\left(\mathrm{C}_{11}\right)$ was calculated using wooster's empirical relation ${ }^{17}(2)$ shown in the Fig. 9b and the values are moderate due to the strong binding forces of the ions.

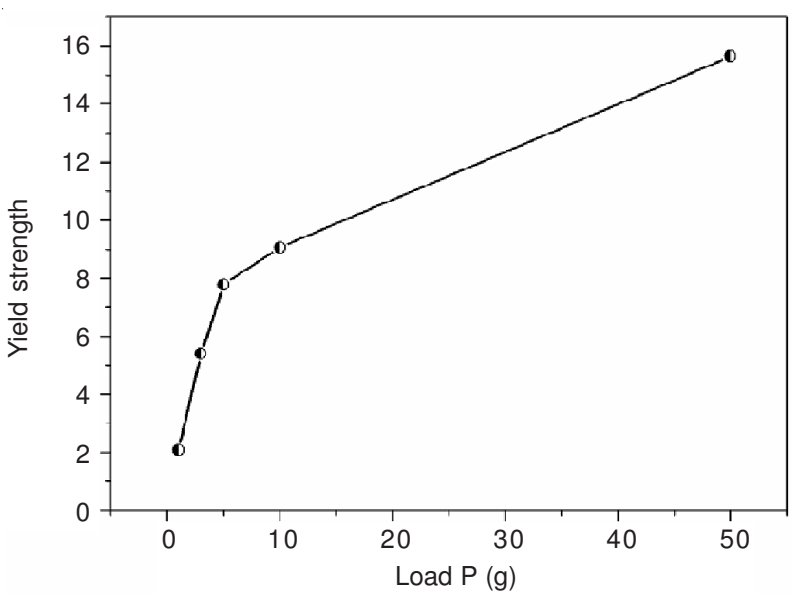

(a)

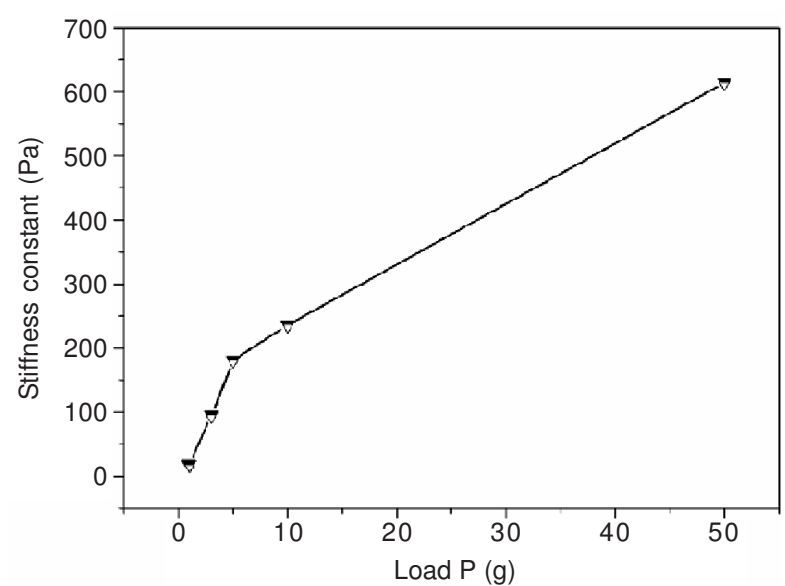

(b)

Fig. 9. (a) Variation of yield strength with load. (b) Variation of stiffness constant with load 


$$
\mathrm{C}_{11}=\mathrm{H}_{\mathrm{V}}^{7 / 4}
$$

A strong green light of $532 \mathrm{~nm}$ was observed indicating high second harmonic generation efficiency of 2A4MPPP using Kurtz-Perry technique ${ }^{13}$. From the obtained data, it is found that SHG efficiency of 2A4MPPP sample is 1.9 times that of well known standard potassium dihydrogen phosphate (KDP) for particle size less than $180 \mu$. The intensity of the second harmonic generation output as a function of particle size was measured is shown in Fig. 10, which indicates 2A4MPPP crystal is a phase-matchable NLO material. This kind of dependence of second harmonic generation on particle size was observed in phase matchable crystals ${ }^{18-20}$.

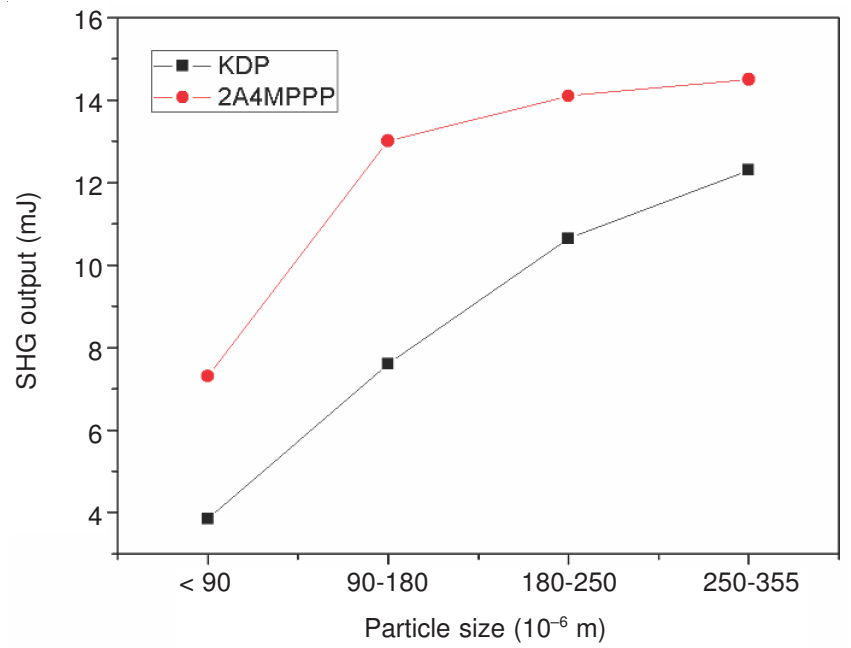

Fig. 10. Second harmonic generation intensity as a function of particle size for potassium dihydrogen phosphate (KDP) and 2A4MPPP powders

The $\mathrm{NO}_{2}$ vibrations are not distinctly seen in Raman. Hence the $\mathrm{NO}_{2}$ group was established highly polarized. It occurred as a result of phenolic $\mathrm{OH}$ proton ionization and the resulting negative charge delocalization. Hence change in the intensity of the peaks due to $\mathrm{NO}_{2}$ vibration in the Raman spectrum is indicative of NLO efficiency of materials. Higher the decreased intensity, higher is the polarization and hence higher the NLO efficiency.

\section{Conclusion}

2-Amino-4-methylpyridinium-4-nitrophenolate-4-nitrophenol crystal was grown by slow evaporation solution growth technique at room temperature using ethanol as solvent. The crystal structure of the title compound, $\mathrm{C}_{18} \mathrm{H}_{18} \mathrm{~N}_{4} \mathrm{O}_{6}$, was determined by X-ray diffraction at $293 \mathrm{~K}$. The title compound belongs to the orthorhombic system with space group Pna $2_{1}$ having four molecules in the unit cell. The lattice parameters are $\mathrm{a}=13.0726(6) \AA, \mathrm{b}=11.8157(4) \AA, \mathrm{c}=12.0281(5) \AA$ and with a cell volume of $1857.88(13) \AA^{3}$. FT-IR, FT-Raman, UVDRS spectrum was used to characterize the title compound. The UV-DRS spectrum shows less absorption in the region $500-800 \mathrm{~nm}$. Thermal stability of the crystal has been explored by TG-DSC analysis which confirmed the crystal for NLO applications up to $98^{\circ} \mathrm{C}$ and also the crystal does not decompose before melting. From the micro-hardness study, yield strength, stiffness constants are calculated. The second harmonic generation efficiency of the title compound is high and powder test shows that the 2A4MPPP crystal is phase-matchable. Hence the aforesaid results make $2 \mathrm{~A} 4 \mathrm{MPPP}$ crystal a potential candidate for NLO applications.

\section{ACKNOWLEDGEMENTS}

The authors thank Prof. M. Palanichamy, Department of Chemistry, Anna University, Chennai, India for his fruitful discussions. Thanks are also due to Dr. M. Basheer Ahamed, Professor of Physics, B.S. Abdur Rahman University, Chennai, India, for his support in SHG measurements.

\section{REFERENCES}

1. I. Prigogine and E. Xhroutes, Physica, 15, 913 (1949).

2. P.N. Prasad and D.J. Wollians, Introduction to Nonlinear Optical Effects in Molecules and Polymers, Wiley-Interscience, New York (1991).

3. K. Takayanagi, Progr. Theoret. Phys. (Kyoto), 6, 486 (1951).

4. B. Shizgal and M. Karplus, J. Chem. Phys., 52, 4262 (1970).

5. J. Zyss, Molecular Nonlinear Optics, Materials Physics devices, Academic Press., Bostan (1994).

6. A. Yokoo, S. Tamaru, L. Yokohama, H. Ito and T. Kaino, J. Cryst. Growth., 156, 279 (1995).

7. F. Pan, C. Bosshard, M.S. Wong,C. Serbutoviezt, S. Follonier, P. Gunter and K. Schenk, J. Cryst. Growth, 165, 273 (1996).

8. J.L. Quader, J. Chem. Phys., 67, 446 (1977).

9. S.J. Lalama and A.F. Garito, Phys. Rev., A20, 1179 (1979).

10. B.F. Levine, C. Bethea, C.D. Thurmond, R.T. Lynch and J.L. Bernstein, J. Appl. Phys., 50, 2523 (1979).

11. P. Srinivasan, T. Kanagasekaran, N. Vijayan, G. Bhagavannarayana, R. Gopalakrishnan and P. Ramasamy, Opt. Mater, 30, 553 (2007).

12. G. Anandha Babu, R.P. Ramasamy and P. Ramasamy, Mater. Chem. Phys., 117, 326 (2009).

13. S.K. Kurtz and T.T. Perry, J. Appl. Phys., 39, 3798 (1968).

14. R.M. Silverstein and F.X. Webster, In: Spectrometric Identification of Organic Compounds, Wiley, New York, edn. 6 (1997).

15. E.M. Onitsch, Mikroscopic, 2, 131 (1947)

16. R.C. Dhas, J.C. Bennet and F.D. Gnanam, J. Cryst. Growth, 137, 295 (1994).

17. W.A. Wooster, Rep. Prog. Phys., 16, 62 (1953).

18. T. Chen, Z. Sun, C. Song, Y. Ge, J. Luo, W. Lin and M. Hong, Cryst. Growth Des., 12, 2673 (2012).

19. L.N. Wang, X.Q. Wang, G.H. Zhang, X.T. Liu, Z.H. Sun, G.H. Sun, L. Wang, W.T. Yu and D. Xu, J. Cryst. Growth, 327, 133 (2011).

20. M. Parthasarathy, M. Anantharaja and R. Gopalakrishnan, J. Cryst. Growth, 340, 118 (2012). 